\title{
Potent macrocycle inhibitors of the human SAGA deubiquitinating module
}

\author{
Michael Morgan ${ }^{1}$, Tatsuya Ikenoue $^{2}$, Hiroaki Suga ${ }^{2 *}$, and Cynthia Wolberger ${ }^{1 *}$
}

${ }^{1}$ Department of Biophysics and Biophysical Chemistry, Johns Hopkins University School of Medicine, Baltimore, MD 21205 USA

${ }^{2}$ Graduate School of Science, The University of Tokyo, Hongo, Bunkyo-ku, Tokyo 113-

0033, Japan

${ }^{*}$ Corresponding author:

Cynthia Wolberger

cwolberg@jhmi.edu

(410)955-0728 


\section{Abstract}

The SAGA complex is a transcriptional coactivator that plays multiple roles in activating transcription and is conserved from yeast to humans. One of SAGA's activities is the removal of ubiquitin from histone $\mathrm{H} 2 \mathrm{~B}-\mathrm{K} 120$ by the deubiquitinating module (DUBm), a four-protein subcomplex containing the catalytic subunit, USP22, bound to three proteins that are required for catalytic activity and targeting to nucleosomes.

Overexpression of USP22 is correlated with cancers with a poor prognosis that are resistant to available therapies. We used the RaPID (Random non-standard Peptides Integrated Discovery) system to identify cyclic peptides that are potent and highly specific inhibitors of USP22. Peptide binding did not impact the overall integrity of the DUBm complex as judged by small-angle x-ray scattering, indicating that the inhibitors do not disrupt subunit interactions required for USP22 activity. Cells treated with peptide had increased levels of H2B monoubiquitination, demonstrating the ability of the cyclic peptides to enter human cells and inhibit H2B deubiquitination. The macrocycle inhibitors we have identified in this work thus exhibit favorable drug-like properties and constitute, to our knowledge, the first reported inhibitors of USP22/SAGA DUB module. 


\section{Introduction}

Histone ubiquitination serves a non-degradative role in regulating transcription (Zhang, 2003, Henry et al., 2003, Turner et al., 2002), DNA repair (Moyal et al., 2011), DNA replication (Somasagara et al., 2017, Hung et al., 2017), and chromatin condensation (Fierz et al., 2011). Monoubiquitination of histone H2B (H2B-Ub) at lysine 120 in humans and lysine 123 (Robzyk et al., 2000) in yeast is a hallmark of actively transcribed genes (Weake and Workman, 2008). H2B-Ub plays a variety of roles in transcription, including promoting assembly of the pre-initiation complex (PIC) (Kao et al., 2004, Turner et al., 2002) and stimulating nucleosome reassembly by the histone chaperone, FACT (Fleming et al., 2008, Pavri et al., 2006). H2B-Ub also stimulates H3K4 methylation by human MLL1 and yeast COMPASS (Sun and Allis, 2002, Dover et al., 2002, Xue et al., 2019, Kim et al., 2009), and H3K79 methylation by human Dot1L and yeast Dot1 (Briggs et al., 2002, McGinty et al., 2008, Steger et al., 2008, Ng et al., 2002a, Ng et al., 2002b). H2B-Ub is distributed throughout gene bodies and is particularly enriched at transcription start sites (TSSs), (Kao et al., 2004, Schulze et al., 2011). An intriguing aspect of $\mathrm{H} 2 \mathrm{~B}-\mathrm{Ub}$ is that it is a transient mark that is rapidly turned over during transcription, with both ubiquitination and deubiquitination of $\mathrm{H} 2 \mathrm{~B}$ important for maintaining wild type levels of transcription (Batta et al., 2011, Henry et al., 2003, Kao et al., 2004). Deubiquitination of histone H2B plays a role in promoting phosphorylation of the RNA polymerase II CTD by Ctk1, thereby promoting the elongation phase of transcription (Wyce et al., 2007). Studies have shown that genes with low H2B-Ub levels are expressed at higher levels than those with high $\mathrm{H} 2 \mathrm{~B}-\mathrm{Ub}$ (Prenzel et al., 2011, Hahn et al., 2012, Shema et al., 2008). Consistent with findings in 
yeast, surveys of gene expression in primary human cancer cells found that loss of USP22 resulted in changes in transcription at SAGA regulated genes (Atanassov et al., 2016).

Altered levels of the enzymes that both attach and remove H2B-Ub are implicated in oncogenesis. Ubiquitin is covalently linked to H2B-K120 in human cells by the E2 ubiquitin conjugating enzyme, hRAD6A/B (Koken et al., 1991) and the E3 ubiquitin ligase, RNF20/40 (Kim et al., 2005). Misregulation of both the E2 and E3 enzymes that monoubiquitinate $\mathrm{H} 2 \mathrm{~B}$ have been shown to result in overexpression of genes that drive cell proliferation (Hung et al., 2017, Shema et al., 2008, Somasagara et al., 2017). A number of different deubiquitinating enzymes (DUBs) remove ubiquitin from $\mathrm{H} 2 \mathrm{~B}$ at distinct subsets of genes, including USP22, USP51, USP27x, USP36, and USP44 (Fuchs et al., 2012, Atanassov et al., 2016, DeVine et al., 2018). Of these DUBs, altered expression of USP22 has been implicated in a variety of tumor types (Melo-Cardenas et al., 2016). USP22 overexpression has been identified as part of an 11- gene "death by cancer" signature of gene expression - a pattern observed over diverse tissue types that is characteristic of metastatic cancers that respond poorly to existing therapies (Glinsky et al., 2005). USP22 overexpression correlates with poor clinical outcomes in tumors of the brain (Li et al., 2013), breast (Zhang et al., 2011), stomach (Yang et al., 2011), liver (Liao et al., 2019, Wen et al., 2020), and colon (Liu et al., 2010, Liu et al., 2012), although its mechanistic role in oncogenesis is poorly understood. In addition, reduced expression of USP22 is associated with chromosomal instability (CIN), since efficient chromosome compaction during mitosis requires USP22 deubiquitination of 
H2B in metaphase (Jeusset et al., 2021). Silencing of USP22 expression results in aberrant chromosomal segregation and phenotypes consistent with CIN, including polyploid daughter cells (Jeusset et al., 2021). Taken together, these findings suggest that appropriate USP22 activity is a critical regulator of major cellular events, and its misregulation is correlated with oncogenesis and genomic heterogeneity.

Because of its role in cancer, USP22 is an attractive target for drug discovery. USP22 is the enzymatic DUB subunit of the SAGA transcriptional coactivator complex, a 1.8 MDa complex comprising 19 subunits that are organized into functional modules (Zhang et al., 2008, Soffers and Workman, 2020). The SAGA complex is conserved from yeast to humans and binds to promoter regions, where SAGA facilitates assembly of the transcriptional pre-initiation complex (Grant et al., 1998a, Grant et al., 1998b, Massari et al., 1999, Sterner et al., 1999), acetylates histone H3 and deubiquitinates histone H2B (reviewed in (Soffers and Workman, 2020)). The deubiquitinating activity of SAGA resides in a four-protein subcomplex called the DUB module (Lee et al., 2009, Kohler et al., 2006, Kohler et al., 2008, Lang et al., 2011, Ingvarsdottir et al., 2005). As first shown in yeast, the catalytic subunit alone is inactive unless incorporated into a complex containing the other three DUB module subunits (Rodriguez-Navarro et al., 2004, Ingvarsdottir et al., 2005, Kohler et al., 2008, Ellisdon et al., 2010). The yeast DUB module comprises the catalytic subunit, Ubp8, in complex with Sgf73, Sgf11, and Sus1 (Henry et al., 2003, Ingvarsdottir et al., 2005, Rodriguez-Navarro et al., 2004, Kohler et al., 2010, Samara et al., 2010). Crystal structures of the yeast DUB module revealed a remarkably intertwined subunit arrangement in which each subunit contacts the other 
three (Kohler et al., 2010, Samara et al., 2010). Deletion or disruption of the interface between Ubp8 and the zinc finger domain of Sgf11, which anchors the DUB module to the nucleosome acidic patch (Morgan et al., 2016), destabilizes intersubunit interactions and abrogates enzymatic activity (Morgan et al., 2016, Samara et al., 2012, Yan and Wolberger, 2015, Wang et al., 2020, Kohler et al., 2010). The human DUB module contains the catalytic subunit, USP22, in complex with ATXN7 (homologue of Sgf73), ATXN7L3 (homologue of Sgf11), and ENY2 (homologue of Sus1) (Zhao et al., 2008, Zhang et al., 2008). Like its yeast homologue, USP22 depends on its partner subunits for full activity (Atanassov et al., 2016), which makes it necessary to utilize the full human DUB module in screens for novel inhibitors.

We report here the results of a screen for macrocyclic peptide inhibitors that target USP22. Using the human SAGA DUB module containing USP22 bound to its three partner proteins, we performed a high-throughput screen of a combinatorial library of structurally unique cyclic peptides that bind tightly to the DUB module. We identified six peptides that inhibit DUB module activity at sub-micromolar concentrations on both a ubiquitin-AMC and nucleosomal substrates. The most potent peptide inhibitor, which has an apparent $\mathrm{K}_{\mathrm{i}}$ of about $20 \mathrm{nM}$ on the human DUB module, did not inhibit several other human DUBs, indicating that it is highly specific for USP22. The cyclic peptides increased H2B-Ub levels in cultured cells, indicating that the peptides can also inhibit DUBs in vivo. These compounds are promising leads as treatments for cancers in which USP22 overexpression may be a factor. 


\section{RESULTS}

\section{Screen for macrocyclic peptides that inhibit the DUB module}

We employed the RaPID system to screen libraries of over $10^{12}$ unique macrocyclic peptides (Hipolito and Suga, 2012, Ito et al., 2015) to identify candidate inhibitors based on their ability to bind tightly to the human DUB module (hDUBm) or yeast DUB modules (yDUBm) (Figure 1A). A puromycin-ligated mRNA library was constructed to encode peptides with $\mathrm{N}$-chloroacetyl-L-Tyrosine ( ${ }^{\mathrm{L}}$-library) or $N$-chloroacetyl-DTyrosine (DY-library) as the initiator amino acid, followed by a random peptide region consisting of 6-15 residues, a cysteine and ending with a short linker peptide. Upon translation of these mRNAs, the chloroacetyl group on $\mathrm{N}$-terminus of the linear peptides spontaneously cyclizes with the downstream cysteine to form thioether-macrocyclic peptides. The cyclic scaffold ensured that the ${ }^{\mathrm{L}}$-library and the ${ }^{\mathrm{D}} \mathrm{Y}$-library diversified three-dimensional structures. Each cyclic peptide was covalently linked to its corresponding mRNA template via the puromycin linker for later amplification and DNA sequencing. These libraries were applied to streptavidin-conjugated magnetic beads to which a N-terminally biotinylated hDUBm or yDUBm was immobilized for selection of ligands against each enzyme complex.

Following four or five rounds of selection, the recovery rate of peptide-mRNA fusion molecules was significantly increased (Figure S1), suggesting that the population of cyclic peptides binding hDUBm or yDUBm were selectively enriched. Sequence analysis of the respective enriched libraries yielded unique sequences for the peptides. 
We selected the six most enriched cyclic peptides for hDUBm and two sequences targeting yDUBm on the basis of the hit frequency for further analysis.

\section{Peptides are potent inhibitors of the human DUB module}

The cyclic peptides that constituted potential inhibitors were chemically synthesized by solid phase peptide synthesis and tested for their effectiveness and specificity as inhibitors in vitro. Since the enzyme kinetics of the human DUB module had not previously been characterized, we first assayed hDUBm activity using the fluorogenic substrate, ubiquitin-amino methyl coumarin (Ub-AMC) (Figure 2A). We then assayed the ability of each cyclic peptide to inhibit DUB module cleavage of Ub-AMC cleavage over a range of concentrations under standardized enzymatic conditions. As shown in Figures $2 B-2 G$, all six peptides that were identified based on their tight binding to the human DUB module were also potent inhibitors of DUB activity. All peptides had submicromolar $\mathrm{K}_{\mathrm{i}}$ values, with the $\mathrm{hL1}, \mathrm{hD1}$, $\mathrm{hD2}$, and $\mathrm{hD} 3$ peptides exhibiting $\mathrm{K}_{\mathrm{i}}$ values of $<100 \mathrm{nM}$. The most potent inhibitor, hD1, had an apparent $\mathrm{K}_{\mathrm{i}}$ of $20.6 \mathrm{nM}$.

The two peptides targeting the yeast DUB module were not pursued as inhibitors, as yL1 was insoluble in aqueous conditions and yD1 did not inhibit activity of the yeast DUB module (Figure S2A). Since yD1 also did not inhibit the human DUBm (Figure S2B), nor was it enriched in the screen for peptides that bind tightly to the human DUBm, this peptide was used for control experiments. 
To test the effectiveness of the inhibitors on a native-like substrate, we assayed the ability of each cyclic peptide to inhibit DUB activity on nucleosomes ubiquitinated at H2B-K120. A denaturing gel was used to monitor cleavage of $\mathrm{H} 2 \mathrm{~B}-\mathrm{Ub}$, releasing $\mathrm{H} 2 \mathrm{~B}$ and $\mathrm{Ub}$ (Figure $2 \mathrm{H}$ ). With the exception of $\mathrm{hD} 4$, all of the cyclic peptide leads were potent inhibitors of nucleosomal H2B-Ub cleavage by the human DUB module (Figures $2 \mathrm{H}$ and $2 \mathrm{I}$ ). Each cyclic peptide sufficiently inhibited hDUB module activity such that no substantial activity was detected over the time course examined. The peptide with the highest $\mathrm{K}_{\mathrm{i}}$ on Ub-AMC, hD4 (804 nM) (Figure 2G), also showed very weak inhibition of hDUBm on nucleosomal H2B-Ub. These results confirm the ability of cyclic peptides $\mathrm{hL} 1, \mathrm{hD} 1, \mathrm{hD} 2, \mathrm{hD} 3$, and hD5 to inhibit the enzymatic activity of USP22/DUB module on a native substrate.

\section{SAXS studies of human DUB module bound to peptide inhibitors}

Most enzyme inhibitors disrupt activity by binding in or near the active site and interfering with substrate binding. Since USP22 is only active when bound to the other DUB module proteins (Lang et al., 2011, Atanassov et al., 2016), another possible mechanism by which the cyclic peptides inhibit USP22 activity could be by altering the interactions between USP22 and the three other subunits, ATXN7, ATXN7L3, and ENY2. Studies of the yeast DUB module showed that deletion of the Sgf11 zinc-finger leads to an inactive domain-swapped dimer of DUB modules (Samara et al., 2012), while mutations made at the interface between Ubp8 and the Sgf11 zinc finger significantly reduce enzyme activity (Kohler et al., 2010). Similarly, disruption of 
intersubunit interactions between the catalytic subunit, Ubp8 (yeast homologue of USP22), and Sgf73 (homologue of ATXN7) cause a loss of DUB activity (Yan and Wolberger, 2015). To see if the USP22 inhibitors altered the overall organization of human DUB module subunits, we used small-angle x-ray scattering (SAXS) to determine whether the DUB module undergoes a large-scale change to its shape in the presence each respective cyclic peptides. Since there is no structure of the human DUB module, we compared the results to predicted SAXS data calculated from the crystal structure of the yeast DUB module (PDB ID: 3MHH) (Samara et al., 2010).

SAXS data were measured with the human DUB module incubated with each respective peptide inhibitor, using DMSO as a vehicle control. The Kratky plot (Fig. 3A) and $p(r)$ distribution (Figure $3 \mathrm{~B}$ ) of the human DUB module in the presence of the hD1 inhibitor are very similar to those of the yeast complex, consistent with the idea that the two complexes adopt a similar tertiary and quaternary structure. A similar trend is seen in SAXS data collected on the human DUB module in the presence of the other cyclic peptides (Supplemental Figure 3), suggesting that the peptides appear to bind the DUB module at discrete surfaces, rather than disrupting the complex. Consistent with this conclusion, ab initio density maps calculated for the human and yeast DUB modules in the presence and absence of hD1 using DENSS analysis (Grant, 2018) indicated minor changes in the molecular envelope. Interestingly, binding of each cyclic peptide slightly increased the long axis of the complex (Figure 3C). The greatest difference in molecular envelope due to peptide binding occurs in the region of the Sgf11/ATXN7L3 zinc finger, 
which is located at one end of the long axis (Figure 3C). We conclude from these data that all of the peptide-bound human DUB module complexes largely maintain their fold.

\section{Inhibitor is selective for human USP22}

In order to probe the relative specificity of the USP22 inhibitors, we tested the effect of hD1 on three human DUBs: the USP7 catalytic domain (USP7CD), USP30, and CYLD. USP7 and USP30 are USP DUBs and thus belong to the same structural family as USP22, while CYLD belongs to the structurally distinct ubiquitin C-terminal hydrolase $(\mathrm{UCH})$ family of DUBs. We tested the activity of hDUBm and each off-target DUB with DMSO (mock) or $1 \mu \mathrm{M}$ hD1. Initial rates of ubiquitin-AMC cleavage were normalized for the intrinsic differences in each enzyme's activity. As shown in Figure 4A, we found that the hD1 peptide had no effect on USP7CD or CYLD activity, and only a very modest $(\sim 15 \%)$ effect on USP30. These results are all the more striking given that the concentration of hD1 inhibitor used was present at 5-10x molar excess and at a concentration that was 50-fold higher than the apparent $K_{i}$ for USP22. Together, these results show that $\mathrm{hD1}$ is a specific inhibitor of the human DUB module.

\section{Cyclic peptide inhibitor increases H2B ubiquitination in cells}

We next asked whether each inhibitor could increase levels of $\mathrm{H} 2 \mathrm{~B}$ ubiquitination in cells, which would be consistent with inhibition of USP22. We introduced each cyclic peptide as a supplement to the growth medium of HEK293T cells, extracted the histones from each culture after two hours of exposure, and quantitated levels of H2BUb by immunoblot. Levels of H2B-Ub were compared to control cells that were treated 
with DMSO, the yD1 cyclic peptide that has no effect on USP22 activity, or the broadspectrum cell permeable DUB inhibitor, PR-619. The relative abundance of histone H3 was used to control for differences in nuclear extraction. As shown in Figure 4B, treatment with five of the six inhibitors significantly increased $\mathrm{H} 2 \mathrm{~B}-\mathrm{Ub}$ levels as compared to the controls. The most dramatic results were observed for hD1 and hD3, which increased H2B-Ub levels in excess of 15-fold, followed by hD4 and hD5, which increased H2B-Ub levels by about 12-fold. The hD2 and hL1 peptides resulted in a minor increase of $\mathrm{H} 2 \mathrm{~B}-\mathrm{Ub}$ on the scale seen with the yD1 control peptide and the DUB inhibitor, PR-619. The robust effect of hD4 in the cell-based assay is interesting given that this was the least effective inhibitor in the Ub-AMC cleavage assay, with an apparent Ki of $804 \mu \mathrm{M}$. Overall, the accumulation of H2B-Ub indicates that the inhibitors are able to enter cells and inhibit DUB module activity. While we cannot rule out an effect on other DUBs that are specific for H2B-Ub, such as USP27x and USP51 (Atanassov et al., 2016), our results are consistent with the ability of these inhibitors to inhibit USP22 in vitro.

\section{Discussion}

Specifically targeting one of the $\sim 90$ human DUBs with inhibitors is difficult because of the high degree of structural similarity within each superfamily. Identifying specific inhibitors of the USP family is particularly challenging because there are 55 USP DUBs, which share a structurally conserved catalytic domain and active site (Clague et al., 2013). Using in vitro selection from a library of cyclic peptides, we identified novel 
inhibitors of USP22, a subunit of the SAGA deubiquitinating module whose overexpression is part of an 11-gene "death by cancer" signature (Glinsky et al., 2005). The most potent of the inhibitors, hD1, inhibited USP22 in vitro with a $K_{i}$ of $20.6 \mathrm{nM}$ (Figure 2C). Importantly, hD1 is highly specific and has little to no effect on the activity of several other human DUBs, including two members of the USP family (Figure 4A). The ability of the peptide inhibitors to increase ubiquitination in cells (Figure 4B, C) indicates that the inhibitor is able to cross the outer cell membrane and enter the nucleus. To our knowledge, the cyclic peptides discussed in this work are the first inhibitors of the human DUB module, potentially offering opportunities for novel therapies and new insights into the roles of USP22 and H2B-Ub signaling in cancer and differentiation.

Five of the six inhibitors tested inhibited USP22/DUBm activity on both Ub-AMC and nucleosomes, suggesting that these inhibitors do not disrupt the docking of the DUBm on the nucleosome. Structural studies of the yeast DUBm showed that only the ubiquitin moiety contacts the USP domain, while the Sgf11 subunit (homologue of ATXN7L3) contacts the nucleosome acidic patch via its arginine-rich zinc finger (Kohler et al., 2010, Samara et al., 2010). Substitutions of the contacting Sgf11 zinc finger arginine residues therefore abrogate activity on nucleosomes but not on Ub-AMC (Morgan et al., 2016). Since the inhibitors we have identified greatly reduce activity on both substrates, they must act by occluding the active site or ubiquitin-binding pocket of USP22, or by disrupting the quaternary organization of the four subunits, thereby abrogating USP22 
activity (Rodriguez-Navarro et al., 2004, Ingvarsdottir et al., 2005). However, SAXS studies of the human DUB module in the presence of inhibitory peptide showed no evidence of a gross conformational change of the type observed for the yeast DUB module upon deletion of the Sgf11 zinc finger (Samara et al., 2012). Interestingly, peptide binding to the human DUB module resulted in modest localized changes in the vicinity of the Sgf11/ATXN7L3 zinc fingers (Figure 3C). While we were unable to obtain crystals of either DUB module bound to an inhibitor, an intriguing possibility is that binding of the peptide inhibitors disrupts the interactions between the Sgf11/ATXN7L3 zinc finger with the USP domain of Ubp8/USP22. Further experiments will be needed to determine the binding location and mechanism of action of the DUB peptide inhibitors.

Our cell-based experiments demonstrated the effectiveness of each macrocycle in enriching H2B-Ub in HEK293T cells (Figure 4B, C). Interestingly, the effect in cells was not strictly correlated with the relative potency of each inhibitor in vitro; the weakest inhibitor of the peptides tested, hD4, has a similar effect on enriching $\mathrm{H} 2 \mathrm{~B}-\mathrm{Ub}$ in cells to the most potent inhibitor, hD1 (Figures 2 and 4A). A plausible explanation is that each peptide enters cells with a different efficiency, although further study will be needed to assess peptide uptake in cells and in tissues. Nevertheless, it is remarkable that $5 \mu \mathrm{M}$ of the macrocyclic peptide, such as hD1, clearly enriched $\mathrm{H} 2 \mathrm{~B}-\mathrm{Ub}$ in cells, suggesting that the inhibitor is active in cells and is membrane permeable at a level comparable to polycationic peptides, so-called cell-penetrating peptides. These results provide strong encouragement to further engineer the macrocycles to improve inhibitory activity against USP22, as well as cell permeability. 
In addition to its role in maintaining H2B-Ub levels, USP22 deubiquitinates several other proteins, including TRF1 (Atanassov et al., 2009), FBP1 (Atanassov and Dent, 2011), and SIRT1 (Lin et al., 2012), complicating the current understanding of how USP22 overexpression impacts cellular events. In mice, USP22 knockout is embryonic lethal, and hypermorphic alleles designed to reduce USP22 expression significantly altered signal transduction for agonists of several receptor tyrosine kinases, resulting in a phenotype that includes developmental aberrations in the placenta and embryo (Koutelou et al., 2019). Misregulated expression of developmental genes driving differentiated cells toward pluripotency can result in cancer progression. However the interplay between the DUB module's roles in chromatin maintenance, transcription factor regulation, and the gene-specific consequences of those combined effects makes it difficult to attribute biological outcomes to any particular USP22 deubiquitination target (Wang and Dent, 2014). The inhibitors we have identified provide new tools to probe the role of USP22 in targeting all of its cellular substrates. 


\section{ACKNOWLEDGEMENTS}

We thank Xiangbin Zhang for assistance in expressing the human DUB module. This work was supported by National Institute of General Medical Sciences grant GM130393 (C.W.) and by Grant-in-Aid for Specially Promote Research JP20H05618 (H.S.) from the Japan Society for the Promotion of Science.

\section{CONFLICT OF INTEREST STATEMENT}

$\mathrm{H}$. Suga is on the board of directors of MiraBiologics. 


\section{METHODS}

\section{Protein expression and purification}

For library screening, Ubp8 and USP22 constructs with N-terminal 6xHis were cloned into expression vectors, extending the $\mathrm{N}$-terminus with an Avi-tag

(GLNDIFEAQKIEWHE), an amino acid sequence that can be specifically biotinylated by the enzyme BirA during expression or in a reconstituted biochemical reaction. The yeast DUB module was expressed and purified as previously described (Samara et al., 2010). Briefly, bacterial cells (BL21-Rosetta2-pLysS) were transformed with three separate plasmids bearing the following coding sequences: Ubp8 (pET32a), Sgf11 and Sgf73 1105 (CDFDuet), and Sus1 (pRSF). Cells were harvested, resuspended in lysis buffer (50 mM HEPES pH 7.8, 500 mM NaCl, 20 mM imidazole, $50 \mu \mathrm{M} \mathrm{ZnCl2,} \mathrm{5 \%} \mathrm{glycerol,} 15$ $\mathrm{mM}$ betamercaptoethanol, and $1 \mathrm{mM}$ PMSF) and lysed using a microfludizer (Microfluidics, Inc.) followed by passage over a HisTrap column (GE Healthcare) and elution with a 20-400 mM imidazole gradient in lysis buffer. Peak fractions were collected and dialyzed into IEX buffer (20 mM HEPES pH 7.6, $50 \mathrm{mM} \mathrm{NaCl}, 20 \mu \mathrm{M}$ $\mathrm{ZnCl} 2,15 \mathrm{mM}$ betamercaptoethanol, and $5 \%$ glycerol), followed by further purification with a Q-SP column (GE Healthcare) using a $0.05-1 \mathrm{M}$ salt gradient in the same buffer. Fractions containing the yeast DUB module were then pooled, concentrated, and injected onto a Superdex 200 10/300 column (GE Healthcare) equilibrated with storage buffer (20 mM HEPES pH 7.6, $150 \mathrm{mM} \mathrm{NaCl}, 20 \mu \mathrm{M}$ ZnCl2, $5 \mathrm{mM} \mathrm{DTT}$, and 5\% glycerol). Peak fractions were pooled, concentrate/ed and flash-frozen in aliquots. 
The human DUBm was expressed using a baculovirus plasmid construct containing all four subunits, USP22, ATXN7(3-151), ATXN7L3, and ENY2, using the Bac2Bac system (Thermo), which we used to transfect Sf9 insect cells in order to amplify the resultant baculovirus. High Five cells were infected with the hDUBm baculovirus for two days, harvested, lysed, and purified in the same buffers used for yDUBm. After purification, recombinant BirA was added to the purified complexes in the presence of $50 \mathrm{mM}$ biotin to produce the biotinylated complex, which was suitable for immobilization and mRNA display screening.

All biochemical and biophysical assays used yDUBm or hDUBm constructs lacking the Avi tag, which were purified essentially as described for their Avi-tagged counterparts, with the exception that the 6xHis affinity tag was cleaved from Ubp8 and USP22 by addition of TEV protease following HisTrap purification and repassage of the ensuing product over the HisTrap column to remove the cleaved tag and protease.

\section{Screening of DUBm binding macrocyclic peptides with the RaPID system}

In vitro selections of DUBm binding macrocyclic peptides using RaPID system was performed as previously reported (Ito et al., 2015) with slight modification. Briefly, the initial random mRNA library was transcribed and ligated to a puromycin linker primer via T4 ligase for $30 \mathrm{~min}$ at $25^{\circ} \mathrm{C}$ and extracted with phenol/chloroform and ethanol precipitated. A $150 \mu \mathrm{L}$ translation reaction using the methionine-deficient FIT system (Goto et al., 2011) and a $50 \mu \mathrm{M}$ concentration of CIAc-L-Tyr-tRNA ${ }^{\text {fMet }}$ CAU and CIAc-DTyr-tRNA ${ }^{\text {fMet }}$ CAU were used to convert the mRNA library into a library of peptide-mRNA 
fusions. The translation was performed at $37^{\circ} \mathrm{C}$ for $30 \mathrm{~min}$ followed by a $25^{\circ} \mathrm{C}$ step for 12 min to enhance the formation of the peptide-mRNA fusions. Thirty microliters of $100 \mathrm{mM}$ EDTA was added to dissociate ribosomes and the peptide-mRNA fusions were incubated at $37^{\circ} \mathrm{C}$ for 30 min to allow the thioether cyclizations to approach completion. The fused peptide-mRNA was subsequently reverse transcribed using MMLV RT RNase $\mathrm{H}$ - (Promega) for $1 \mathrm{~h}$ at $42^{\circ} \mathrm{C}$ and $0.5 \mu \mathrm{L}$ aliquot of the peptide-mRNA fusions was taken from the mixture and saved for the determination of the total amount of inputted mRNA. The peptide-mRNA fusions were then incubated with human and yeast DUBm-immobilized on Dynabeads M-280 streptavidin (Invitrogen) for 30 min at $37^{\circ} \mathrm{C}$. The resultant complementary DNAs were eluted by mixing with $1 \times$ PCR reaction buffer and heating at $95^{\circ} \mathrm{C}$ for $5 \mathrm{~min}$, followed by immediate separation of the supernatant from the beads. A small fraction of the cDNA and input were allocated to real-time PCR quantification using a LightCycler 2.0 (Roche); the remainder was amplified by PCR. The resulting duplex DNAs were purified by phenol-chloroform extraction and ethanol precipitation, and transcribed into mRNAs for the next round of selection. From the second round of selection, the translation was performed at $5 \mu \mathrm{L}$ scale, and six times of pre-clear steps were added as negative selection preceding the positive selection steps using $1 \mu \mathrm{L}$ each of untreated and biotin bound Dynabeads. Finally, the observed enrichments appearing at fifth and sixth round were subjected to further DNA deep sequencing using the MiSeq sequencing system (Ilumina).

\section{Chemical synthesis of peptides}


Macrocyclic peptides were synthesized by standard Fmoc solid-phase peptide synthesis (SPPS) using a Syro Wave automated peptide synthesizer (Biotage). The resulting peptide-resin $(25 \mu \mathrm{mol}$ scale) was treated with a solution of $92.5 \%$ trifluoroacetic acid (TFA), $2.5 \%$ water, $2.5 \%$ triisopropylsilane and $2.5 \%$ ethanedithiol, to yield the free linear N-CIAc-peptide. Following diethyl ether precipitation, the pellet was dissolved in $10 \mathrm{ml}$ triethylamine containing DMSO and incubated for $1 \mathrm{~h}$ at $25^{\circ} \mathrm{C}$, to yield the corresponding macrocycle. The peptide suspensions were then acidified by addition of TFA to quench the macrocyclization reaction. The macrocycle was purified by RPHPLC, using a Prominence HPLC system (Shimadzu) under linear gradient conditions. Mobile phase $A$ (comprising water with $0.1 \%$ TFA) was mixed with mobile phase $B$ (0.1\% TFA in acetonitrile). Purified peptides were lyophilized in vacuo and molecular mass was confirmed by MALDI MS, using an AutoFlex II instrument (Bruker Daltonics).

\section{Ub-AMC deubiquitination assay}

A working stock mixture of either yDUBm or hDUBm was prepared in the presence of either DMSO (mock) or a dilution series of the cyclic peptide. Before making the stock mix, the enzyme complex was diluted in reaction buffer (50 mM HEPES, pH 7.5, 150 $\mathrm{mM} \mathrm{NaCl}, 1 \mu \mathrm{M} \mathrm{ZnCl}$, and $5 \mathrm{mM}$ DTT), and each cyclic peptide was serially diluted with DMSO from 1.6 mM in 2-fold increments to make 15x stocks of each desired final peptide concentration (so as to keep DMSO concentration constant in all reactions), then diluted in buffer before mixing with enzyme. Each enzyme:peptide mixture was incubated for $30 \mathrm{~min}$ at $30^{\circ} \mathrm{C}$ in the case of $\mathrm{yDUBm}$, and $37^{\circ} \mathrm{C}$ in the case of hDUBm, with each enzyme complex at 1.033x the desired concentration (207 nM). We added 29 
$\mu \mathrm{M}$ of the enzyme:peptide mixture to $1 \mathrm{uL}$ of $30 \mu \mathrm{M}$ Ub-AMC (7-amino-4-

methylcoumarin) (Boston Biochem), for a final concentration of 200 nM DUBm, the indicated cyclic peptide concentration, and $1 \mu \mathrm{M}$ Ub-AMC. DUB activity was measured by observing the increase in AMC fluorescence in a plate reader, and the initial rate of fluorescence increase was calculated and plotted as a function of inhibitor concentration (Figure 2B-I). The $K_{i}$ values were determined using the Morrison approximation of enzyme inhibition equilibria (Kuzmic et al., 2000) within Prism (Graphpad).

\section{Deubiquitination of nucleosomal H2B}

Recombinant human mononucleosomes containing histone H2B ubiquitinated at K120 (H2B-Ub) were obtained from Epicypher (dNuc, 16-0370) and diluted to $2 \mu \mathrm{M}$ with reaction buffer. Both hDUBm and inhibitor peptides were diluted from concentrated stocks with reaction buffer (10 mM HEPES pH 7.5, $150 \mathrm{mM} \mathrm{NaCl}, 1 \mu \mathrm{M} \mathrm{ZnCl}$, and 0.2 $\mathrm{mM}$ TCEP) to a final concentration of $400 \mathrm{nM}$ DUB module and $2 \mu \mathrm{M}$ cyclic peptide and incubated at $37^{\circ} \mathrm{C}$ for 20 minutes. Reactions were initiated by combining equal volumes of the enzyme-peptide mixture and nucleosomes, resulting in final concentrations of 200 $\mathrm{nM}$ hDUBm, $1 \mu \mathrm{M}$ cyclic peptide, and $1 \mathrm{uM} \mathrm{H}$ 2B-Ub nucleosome. Time points of the reaction were quenched with SDS sample buffer, separated by SDS-PAGE (Invitrogen, Bolt gels), and stained with Sypro Ruby (Life Technologies). Gels were imaged and quantitated (BioRad product info), using the $\mathrm{H} 3$ band as an independent load control to normalize the band intensities of H2B-Ub. Experiments were done in triplicate and analyzed using Prism (GraphPad). 


\section{Small-angle x-ray scattering}

Small angle x-ray scattering data (SAXS) were collected on a Rigaku BioSAXS 2000 instrument mounted on a Rigaku FRE-Super Bright rotating anode x-ray generator. The yeast and human DUBm and DUBm were diluted to concentrations of $1 \mathrm{mg} / \mathrm{mL}(6 \mu \mathrm{M})$ in reaction buffer (see H2B-Ub DUB assay) and scattering data recorded with a Pilatus$6 \mathrm{M}$ detector. To record SAXS data from each DUBm in the presence of cyclic peptide, both peptide and DUBm were incubated at equimolar concentration $(6 \mu \mathrm{M})$. Data were analyzed using the Primus suite of SAXS analysis software to obtain $p(r)$ curves. These data were then processed further using the DENSS algorithm to produce electron density maps. Maps were then further analyzed using UCSF Chimera. (Add how you calculated theoretical curves and maps from the structure).

\section{Cell-based Assay}

HEK293T cells were purchased from ATCC (CRL-3216) and cultures were expanded for at least 10 passages in Dulbecco's Modified Eagle Medium (DMEM) supplemented with $10 \%$ fetal bovine serum (FBS) in $\mathrm{T} 75$ flasks incubated in a $37^{\circ} \mathrm{C}$ and $5 \% \mathrm{CO} 2$ cabinet before any manipulation. Once cells were mature, HEK293T cells were grown to $80 \%$ confluence in 6 -well plates, the media were aspirated, and media with reduced FBS (DMEM, 2\% FBS) and $5 \mu \mathrm{M}$ cyclic peptide were introduced. After two hours, the media were aspirated, and the cells were collected by scraping $\left(\sim 1 \times 10^{6}\right.$ cells per well). The cells were then washed in 1x PBS twice followed by histone extraction (Active 
bioRxiv preprint doi: https://doi.org/10.1101/2021.05.13.444038; this version posted May 14,2021 . The copyright holder for this preprint (which

was not certified by peer review) is the author/funder, who has granted bioRxiv a license to display the preprint in perpetuity. It is made available under aCC-BY 4.0 International license.

Motif). The extracted histones were then western blotted for H2B-Ub levels (Cell

Signaling, 5546S), using H3 western blotting (Abcam, ab1791) to normalize loading. 


\section{REFERENCES}

ATANASSOV, B. S. \& DENT, S. Y. 2011. USP22 regulates cell proliferation by deubiquitinating the transcriptional regulator FBP1. EMBO Rep, 12, 924-30.

ATANASSOV, B. S., EVRARD, Y. A., MULTANI, A. S., ZHANG, Z., TORA, L., DEVYS, D., CHANG, S. \& DENT, S. Y. 2009. Gcn5 and SAGA regulate shelterin protein turnover and telomere maintenance. Mol Cell, 35, 352-64.

ATANASSOV, B. S., MOHAN, R. D., LAN, X., KUANG, X., LU, Y., LIN, K., MCIVOR, E., LI, W., ZHANG, Y., FLORENS, L., BYRUM, S. D., MACKINTOSH, S. G., CALHOUN-DAVIS, T., KOUTELOU, E., WANG, L., TANG, D. G., TACKETT, A. J., WASHBURN, M. P., WORKMAN, J. L. \& DENT, S. Y. 2016. ATXN7L3 and ENY2 Coordinate Activity of Multiple H2B Deubiquitinases Important for Cellular Proliferation and Tumor Growth. Mol Cell, 62, 558-71.

BATTA, K., ZHANG, Z., YEN, K., GOFFMAN, D. B. \& PUGH, B. F. 2011. Genome-wide function of H2B ubiquitylation in promoter and genic regions. Genes Dev, 25, 2254-65.

BRIGGS, S. D., XIAO, T., SUN, Z. W., CALDWELL, J. A., SHABANOWITZ, J., HUNT, D. F., ALLIS, C. D. \& STRAHL, B. D. 2002. Gene silencing: trans-histone regulatory pathway in chromatin. Nature, 418, 498.

CLAGUE, M. J., BARSUKOV, I., COULSON, J. M., LIU, H., RIGDEN, D. J. \& URBE, S. 2013. Deubiquitylases from genes to organism. Physiol Rev, 93, 1289-315.

DEVINE, T., SEARS, R. C. \& DAI, M. S. 2018. The ubiquitin-specific protease USP36 is a conserved histone H2B deubiquitinase. Biochem Biophys Res Commun, 495, 2363-2368.

DOVER, J., SCHNEIDER, J., TAWIAH-BOATENG, M. A., WOOD, A., DEAN, K., JOHNSTON, M. \& SHILATIFARD, A. 2002. Methylation of histone $\mathrm{H} 3$ by COMPASS requires ubiquitination of histone H2B by Rad6. J Biol Chem, 277, 28368-71.

ELLISDON, A. M., JANI, D., KOHLER, A., HURT, E. \& STEWART, M. 2010. Structural basis for the interaction between yeast Spt-Ada-Gcn5 acetyltransferase (SAGA) complex components Sgf11 and Sus1. J Biol Chem, 285, 3850-3856.

FIERZ, B., CHATTERJEE, C., MCGINTY, R. K., BAR-DAGAN, M., RALEIGH, D. P. \& MUIR, T. W. 2011. Histone H2B ubiquitylation disrupts local and higher-order chromatin compaction. Nat Chem Biol, 7, 113-9.

FLEMING, A. B., KAO, C. F., HILLYER, C., PIKAART, M. \& OSLEY, M. A. 2008. H2B ubiquitylation plays a role in nucleosome dynamics during transcription elongation. Mol Cell, 31, 57-66.

FUCHS, G., SHEMA, E., VESTERMAN, R., KOTLER, E., WOLCHINSKY, Z., WILDER, S., GOLOMB, L., PRIBLUDA, A., ZHANG, F., HAJ-YAHYA, M., FELDMESSER, E., BRIK, A., YU, X., HANNA, J., ABERDAM, D., DOMANY, E. \& OREN, M. 2012. RNF20 and USP44 regulate stem cell differentiation by modulating $\mathrm{H} 2 \mathrm{~B}$ monoubiquitylation. Mol Cell, 46, 662-73. 
GLINSKY, G. V., BEREZOVSKA, O., GLINSKII, A. B., GLINSKY, G. V., BEREZOVSKA, O. \& GLINSKII, A. B. 2005. Microarray analysis identifies a death-from- cancer signature predicting therapy failure in patients with multiple types of cancer Find the latest version : Microarray analysis identifies a death-from- cancer signature predicting therapy failure in patients with multiple types of cancer.

GOTO, Y., KATOH, T. \& SUGA, H. 2011. Flexizymes for genetic code reprogramming. Nat Protoc, 6, 779-90.

GRANT, P. A., SCHIELTZ, D., PRAY-GRANT, M. G., STEGER, D. J., REESE, J. C., YATES, J. R., 3RD \& WORKMAN, J. L. 1998a. A subset of TAF(II)s are integral components of the SAGA complex required for nucleosome acetylation and transcriptional stimulation. Cell, 94, 45-53.

GRANT, P. A., SCHIELTZ, D., PRAY-GRANT, M. G., YATES, J. R., 3RD \& WORKMAN, J. L. 1998b. The ATM-related cofactor Tra1 is a component of the purified SAGA complex. Mol Cell, 2, 863-7.

GRANT, T. D. 2018. Ab initio electron density determination directly from solution scattering data. Nat Methods, 15, 191-193.

HAHN, M. A., DICKSON, K. A., JACKSON, S., CLARKSON, A., GILL, A. J. \& MARSH, D. J. 2012. The tumor suppressor CDC73 interacts with the ring finger proteins RNF20 and RNF40 and is required for the maintenance of histone 2B monoubiquitination. Hum Mol Genet, 21, 559-68.

HENRY, K. W., WYCE, A., LO, W. S., DUGGAN, L. J., EMRE, N. C., KAO, C. F., PILLUS, L., SHILATIFARD, A., OSLEY, M. A. \& BERGER, S. L. 2003. Transcriptional activation via sequential histone $\mathrm{H} 2 \mathrm{~B}$ ubiquitylation and deubiquitylation, mediated by SAGA-associated Ubp8. Genes Dev, 17, 2648-63.

HIPOLITO, C. J. \& SUGA, H. 2012. Ribosomal production and in vitro selection of natural product-like peptidomimetics: the FIT and RaPID systems. Curr Opin Chem Biol, 16, 196-203.

HUNG, S. H., WONG, R. P., ULRICH, H. D. \& KAO, C. F. 2017. Monoubiquitylation of histone $\mathrm{H} 2 \mathrm{~B}$ contributes to the bypass of DNA damage during and after DNA replication. Proc Natl Acad Sci U S A, 114, E2205-E2214.

INGVARSDOTTIR, K., KROGAN, N. J., EMRE, N. C., WYCE, A., THOMPSON, N. J., EMILI, A., HUGHES, T. R., GREENBLATT, J. F. \& BERGER, S. L. 2005. H2B ubiquitin protease Ubp8 and Sgf11 constitute a discrete functional module within the Saccharomyces cerevisiae SAGA complex. Mol Cell Biol, 25, 1162-72.

ITO, K., SAKAI, K., SUZUKI, Y., OZAWA, N., HATTA, T., NATSUME, T., MATSUMOTO, K. \& SUGA, H. 2015. Artificial human Met agonists based on macrocycle scaffolds. Nat Commun, 6, 6373.

JEUSSET, L. M., GUPPY, B. J., LICHTENSZTEJN, Z., MCDONALD, D. \& MCMANUS, K. J. 2021. Reduced USP22 Expression Impairs Mitotic Removal of H2B Monoubiquitination, Alters Chromatin Compaction and Induces Chromosome Instability That May Promote Oncogenesis. Cancers, 13. 
KAO, C. F., HILLYER, C., TSUKUDA, T., HENRY, K., BERGER, S. \& OSLEY, M. A. 2004. Rad6 plays a role in transcriptional activation through ubiquitylation of histone H2B. Genes Dev, 18, 184-95.

KIM, J., GUERMAH, M., MCGINTY, R. K., LEE, J. S., TANG, Z., MILNE, T. A., SHILATIFARD, A., MUIR, T. W. \& ROEDER, R. G. 2009. RAD6-Mediated transcription-coupled $\mathrm{H} 2 \mathrm{~B}$ ubiquitylation directly stimulates $\mathrm{H} 3 \mathrm{~K} 4$ methylation in human cells. Cell, 137, 459-71.

KIM, J., HAKE, S. B. \& ROEDER, R. G. 2005. The human homolog of yeast BRE1 functions as a transcriptional coactivator through direct activator interactions. $\mathrm{Mol}$ Cell, 20, 759-70.

KOHLER, A., PASCUAL-GARCIA, P., LLOPIS, A., ZAPATER, M., POSAS, F., HURT, E. \& RODRIGUEZ-NAVARRO, S. 2006. The mRNA export factor Sus1 is involved in Spt/Ada/Gcn5 acetyltransferase-mediated H2B deubiquitinylation through its interaction with Ubp8 and Sgf11. Mol Biol Cell, 17, 4228-36.

KOHLER, A., SCHNEIDER, M., CABAL, G. G., NEHRBASS, U. \& HURT, E. 2008. Yeast Ataxin-7 links histone deubiquitination with gene gating and mRNA export. Nat Cell Biol, 10, 707-15.

KOHLER, A., ZIMMERMAN, E., SCHNEIDER, M., HURT, E. \& ZHENG, N. 2010. Structural basis for assembly and activation of the heterotetrameric SAGA histone H2B deubiquitinase module. Cell, 141, 606-17.

KOKEN, M. H., REYNOLDS, P., JASPERS-DEKKER, I., PRAKASH, L., PRAKASH, S., BOOTSMA, D. \& HOEIJMAKERS, J. H. 1991. Structural and functional conservation of two human homologs of the yeast DNA repair gene RAD6. Proc Natl Acad Sci U S A, 88, 8865-9.

KOUTELOU, E., WANG, L., SCHIBLER, A. C., CHAO, H. P., KUANG, X., LIN, K., LU, Y., SHEN, J., JETER, C. R., SALINGER, A., WILSON, M., CHEN, Y. C., ATANASSOV, B. S., TANG, D. G. \& DENT, S. Y. R. 2019. USP22 controls multiple signaling pathways that are essential for vasculature formation in the mouse placenta. Development, 146.

KUZMIC, P., SIDERIS, S., CREGAR, L. M., ELROD, K. C., RICE, K. D. \& JANC, J. W. 2000. High-throughput screening of enzyme inhibitors: automatic determination of tight-binding inhibition constants. Anal Biochem, 281, 62-7.

LANG, G., BONNET, J., UMLAUF, D., KARMODIYA, K., KOFFLER, J., STIERLE, M., DEVYS, D. \& TORA, L. 2011. The tightly controlled deubiquitination activity of the human SAGA complex differentially modifies distinct gene regulatory elements. Mol Cell Biol, 31, 3734-44.

LEE, K. K., SWANSON, S. K., FLORENS, L., WASHBURN, M. P. \& WORKMAN, J. L. 2009. Yeast Sgf73/Ataxin-7 serves to anchor the deubiquitination module into both SAGA and Slik(SALSA) HAT complexes. Epigenetics Chromatin, 2, 2.

LI, Z. H., YU, Y., DU, C., FU, H., WANG, J. \& TIAN, Y. 2013. RNA interferencemediated USP22 gene silencing promotes human brain glioma apoptosis and induces cell cycle arrest. Oncol Lett, 5, 1290-1294. 
LIAO, Y., LIANG, X., LIANG, W., LI, Z., WANG, Y., WANG, L., ZHEN, S., TANG, B. \& WANG, Z. 2019. High expression of ubiquitin carboxyl-terminal hydrolase 22 is associated with poor prognosis in hepatitis B virus-associated liver cancer. Oncol Lett, 17, 5159-5168.

LIN, Z., YANG, H., KONG, Q., LI, J., LEE, S. M., GAO, B., DONG, H., WEI, J., SONG, J., ZHANG, D. D. \& FANG, D. 2012. USP22 antagonizes p53 transcriptional activation by deubiquitinating Sirt1 to suppress cell apoptosis and is required for mouse embryonic development. Mol Cell, 46, 484-94.

LIU, Y., YANG, Y., XU, H. \& DONG, X. 2010. Implication of USP22 in the regulation of BMI-1, c-Myc, p16INK4a, p14ARF, and cyclin D2 expression in primary colorectal carcinomas. Diagn Mol Pathol, 19, 194-200.

LIU, Y. L., JIANG, S. X., YANG, Y. M., XU, H., LIU, J. L. \& WANG, X. S. 2012. USP22 acts as an oncogene by the activation of BMI-1-mediated INK4a/ARF pathway and Akt pathway. Cell Biochem Biophys, 62, 229-35.

MASSARI, M. E., GRANT, P. A., PRAY-GRANT, M. G., BERGER, S. L., WORKMAN, J. L. \& MURRE, C. 1999. A conserved motif present in a class of helix-loop-helix proteins activates transcription by direct recruitment of the SAGA complex. Mol Cell, 4, 63-73.

MCGINTY, R. K., KIM, J., CHATTERJEE, C., ROEDER, R. G. \& MUIR, T. W. 2008. Chemically ubiquitylated histone H2B stimulates hDot1L-mediated intranucleosomal methylation. Nature, 453, 812-6.

MELO-CARDENAS, J., ZHANG, Y., ZHANG, D. D. \& FANG, D. 2016. Ubiquitin-specific peptidase 22 functions and its involvement in disease. Oncotarget, 7, 4484844856.

MORGAN, M. T., HAJ-YAHYA, M., RINGEL, A. E., BANDI, P., BRIK, A. \& WOLBERGER, C. 2016. Structural basis for histone H2B deubiquitination by the SAGA DUB module. Science, 351, 725-8.

MOYAL, L., LERENTHAL, Y., GANA-WEISZ, M., MASS, G., SO, S., WANG, S. Y., EPPINK, B., CHUNG, Y. M., SHALEV, G., SHEMA, E., SHKEDY, D., SMORODINSKY, N. I., VAN VLIET, N., KUSTER, B., MANN, M., CIECHANOVER, A., DAHM-DAPHI, J., KANAAR, R., HU, M. C., CHEN, D. J., OREN, M. \& SHILOH, Y. 2011. Requirement of ATM-dependent monoubiquitylation of histone $\mathrm{H} 2 \mathrm{~B}$ for timely repair of DNA double-strand breaks. Mol Cell, 41, 529-42.

NG, H. H., FENG, Q., WANG, H., ERDJUMENT-BROMAGE, H., TEMPST, P., ZHANG, Y. \& STRUHL, K. 2002a. Lysine methylation within the globular domain of histone $\mathrm{H} 3$ by Dot1 is important for telomeric silencing and Sir protein association. Genes Dev, 16, 1518-27.

NG, H. H., XU, R. M., ZHANG, Y. \& STRUHL, K. 2002b. Ubiquitination of histone H2B by Rad6 is required for efficient Dot1-mediated methylation of histone H3 lysine 79. J Biol Chem, 277, 34655-7. 
PAVRI, R., ZHU, B., LI, G., TROJER, P., MANDAL, S., SHILATIFARD, A. \& REINBERG, D. 2006. Histone H2B monoubiquitination functions cooperatively with FACT to regulate elongation by RNA polymerase II. Cell, 125, 703-17.

PRENZEL, T., BEGUS-NAHRMANN, Y., KRAMER, F., HENNION, M., HSU, C., GORSLER, T., HINTERMAIR, C., EICK, D., KREMMER, E., SIMONS, M., BEISSBARTH, T. \& JOHNSEN, S. A. 2011. Estrogen-dependent gene transcription in human breast cancer cells relies upon proteasome-dependent monoubiquitination of histone H2B. Cancer Res, 71, 5739-53.

ROBZYK, K., RECHT, J. \& OSLEY, M. A. 2000. Rad6-dependent ubiquitination of histone H2B in yeast. Science, 287, 501-4.

RODRIGUEZ-NAVARRO, S., FISCHER, T., LUO, M. J., ANTUNEZ, O., BRETTSCHNEIDER, S., LECHNER, J., PEREZ-ORTIN, J. E., REED, R. \& HURT, E. 2004. Sus1, a functional component of the SAGA histone acetylase complex and the nuclear pore-associated mRNA export machinery. Cell, 116, 7586.

SAMARA, N. L., DATTA, A. B., BERNDSEN, C. E., ZHANG, X., YAO, T., COHEN, R. E. \& WOLBERGER, C. 2010. Structural insights into the assembly and function of the SAGA deubiquitinating module. Science, 328, 1025-9.

SAMARA, N. L., RINGEL, A. E. \& WOLBERGER, C. 2012. A role for intersubunit interactions in maintaining SAGA deubiquitinating module structure and activity. Structure, 20, 1414-24.

SCHULZE, J. M., HENTRICH, T., NAKANISHI, S., GUPTA, A., EMBERLY, E., SHILATIFARD, A. \& KOBOR, M. S. 2011. Splitting the task: Ubp8 and Ubp10 deubiquitinate different cellular pools of H2BK123. Genes Dev, 25, 2242-7.

SHEMA, E., TIROSH, I., AYLON, Y., HUANG, J., YE, C., MOSKOVITS, N., RAVERSHAPIRA, N., MINSKY, N., PIRNGRUBER, J., TARCIC, G., HUBLAROVA, P., MOYAL, L., GANA-WEISZ, M., SHILOH, Y., YARDEN, Y., JOHNSEN, S. A., VOJTESEK, B., BERGER, S. L. \& OREN, M. 2008. The histone H2B-specific ubiquitin ligase RNF20/hBRE1 acts as a putative tumor suppressor through selective regulation of gene expression. Genes Dev, 22, 2664-76.

SOFFERS, J. H. M. \& WORKMAN, J. L. 2020. The SAGA chromatin-modifying complex: the sum of its parts is greater than the whole. Genes Dev, 34, 12871303.

SOMASAGARA, R. R., SPENCER, S. M., TRIPATHI, K., CLARK, D. W., MANI, C., MADEIRA DA SILVA, L., SCALICI, J., KOTHAYER, H., WESTWELL, A. D., ROCCONI, R. P. \& PALLE, K. 2017. RAD6 promotes DNA repair and stem cell signaling in ovarian cancer and is a promising therapeutic target to prevent and treat acquired chemoresistance. Oncogene, 36, 6680-6690.

STEGER, D. J., LEFTEROVA, M. I., YING, L., STONESTROM, A. J., SCHUPP, M., ZHUO, D., VAKOC, A. L., KIM, J. E., CHEN, J., LAZAR, M. A., BLOBEL, G. A. \& VAKOC, C. R. 2008. DOT1L/KMT4 recruitment and H3K79 methylation are 
ubiquitously coupled with gene transcription in mammalian cells. Mol Cell Biol, 28, 2825-39.

STERNER, D. E., GRANT, P. A., ROBERTS, S. M., DUGGAN, L. J., BELOTSERKOVSKAYA, R., PACELLA, L. A., WINSTON, F., WORKMAN, J. L. \& BERGER, S. L. 1999. Functional organization of the yeast SAGA complex: distinct components involved in structural integrity, nucleosome acetylation, and TATA-binding protein interaction. Mol Cell Biol, 19, 86-98.

SUN, Z. W. \& ALLIS, C. D. 2002. Ubiquitination of histone H2B regulates H3 methylation and gene silencing in yeast. Nature, 418, 104-8.

TURNER, S. D., RICCI, A. R., PETROPOULOS, H., GENEREAUX, J., SKERJANC, I. S. \& BRANDL, C. J. 2002. The E2 ubiquitin conjugase Rad6 is required for the ArgR/Mcm1 repression of ARG1 transcription. Mol Cell Biol, 22, 4011-9.

WANG, H., DIENEMANN, C., STUTZER, A., URLAUB, H., CHEUNG, A. C. M. \& CRAMER, P. 2020. Structure of the transcription coactivator SAGA. Nature, 577, 717-720.

WANG, L. \& DENT, S. Y. 2014. Functions of SAGA in development and disease. Epigenomics, 6, 329-39.

WEAKE, V. M. \& WORKMAN, J. L. 2008. Histone ubiquitination: triggering gene activity. Mol Cell, 29, 653-63.

WEN, X., LING, S., WU, W., SHAN, Q., LIU, P., WANG, C., WEI, X., DING, W., TENG, X. \& XU, X. 2020. Ubiquitin-Specific Protease 22/Silent Information Regulator 1 Axis Plays a Pivotal Role in the Prognosis and 5-Fluorouracil Resistance in Hepatocellular Carcinoma. Dig Dis Sci, 65, 1064-1073.

WYCE, A., XIAO, T., WHELAN, K. A., KOSMAN, C., WALTER, W., EICK, D., HUGHES, T. R., KROGAN, N. J., STRAHL, B. D. \& BERGER, S. L. 2007. H2B ubiquitylation acts as a barrier to Ctk1 nucleosomal recruitment prior to removal by Ubp8 within a SAGA-related complex. Mol Cell, 27, 275-88.

XUE, H., YAO, T., CAO, M., ZHU, G., LI, Y., YUAN, G., CHEN, Y., LEI, M. \& HUANG, J. 2019. Structural basis of nucleosome recognition and modification by MLL methyltransferases. Nature, 573, 445-449.

YAN, M. \& WOLBERGER, C. 2015. Uncovering the role of Sgf73 in maintaining SAGA deubiquitinating module structure and activity. J Mol Biol, 427, 1765-78.

YANG, D. D., CUI, B. B., SUN, L. Y., ZHENG, H. Q., HUANG, Q., TONG, J. X. \& ZHANG, Q. F. 2011. The co-expression of USP22 and BMI-1 may promote cancer progression and predict therapy failure in gastric carcinoma. Cell Biochem Biophys, 61, 703-10.

ZHANG, X. Y., VARTHI, M., SYKES, S. M., PHILLIPS, C., WARZECHA, C., ZHU, W., WYCE, A., THORNE, A. W., BERGER, S. L. \& MCMAHON, S. B. 2008. The putative cancer stem cell marker USP22 is a subunit of the human SAGA complex required for activated transcription and cell-cycle progression. Mol Cell, 29, 102-11. 
ZHANG, Y. 2003. Transcriptional regulation by histone ubiquitination and deubiquitination. Genes Dev, 17, 2733-40.

ZHANG, Y., YAO, L., ZHANG, X., JI, H., WANG, L., SUN, S. \& PANG, D. 2011. Elevated expression of USP22 in correlation with poor prognosis in patients with invasive breast cancer. J Cancer Res Clin Oncol, 137, 1245-53.

ZHAO, Y., LANG, G., ITO, S., BONNET, J., METZGER, E., SAWATSUBASHI, S., SUZUKI, E., LE GUEZENNEC, X., STUNNENBERG, H. G., KRASNOV, A., GEORGIEVA, S. G., SCHULE, R., TAKEYAMA, K., KATO, S., TORA, L. \& DEVYS, D. 2008. A TFTC/STAGA module mediates histone $\mathrm{H} 2 \mathrm{~A}$ and $\mathrm{H} 2 \mathrm{~B}$ deubiquitination, coactivates nuclear receptors, and counteracts heterochromatin silencing. Mol Cell, 29, 92-101. 


\section{Figure 1}

A

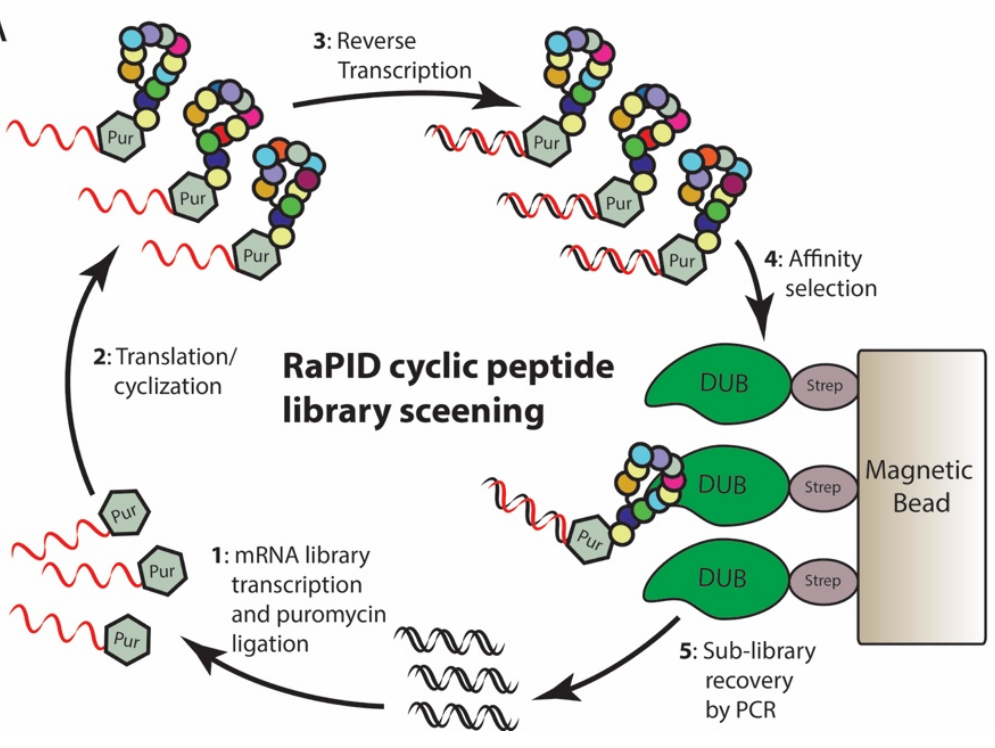

B

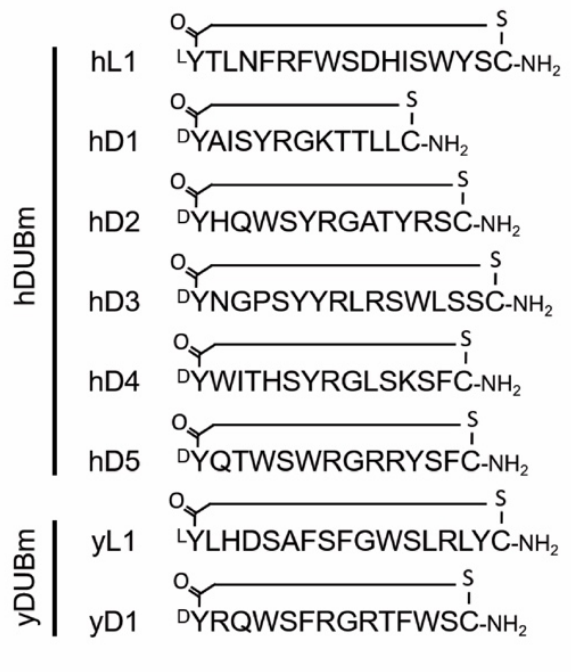

Figure 1 - RaPID cyclic peptide library screening: A) Schematic of Random nonstandard Peptide Integration Discovery platform used for targeting the SAGA DUB module for novel binding species. B) Sequences for each peptide selected from RaPID screen for further evaluation as inhibitors. Each peptide contains the indicated D- or L-amino acid at the $\mathrm{N}$-terminus covalently linked to the C-terminal cysteine sulfhydryl group. 


\section{Figure 2}
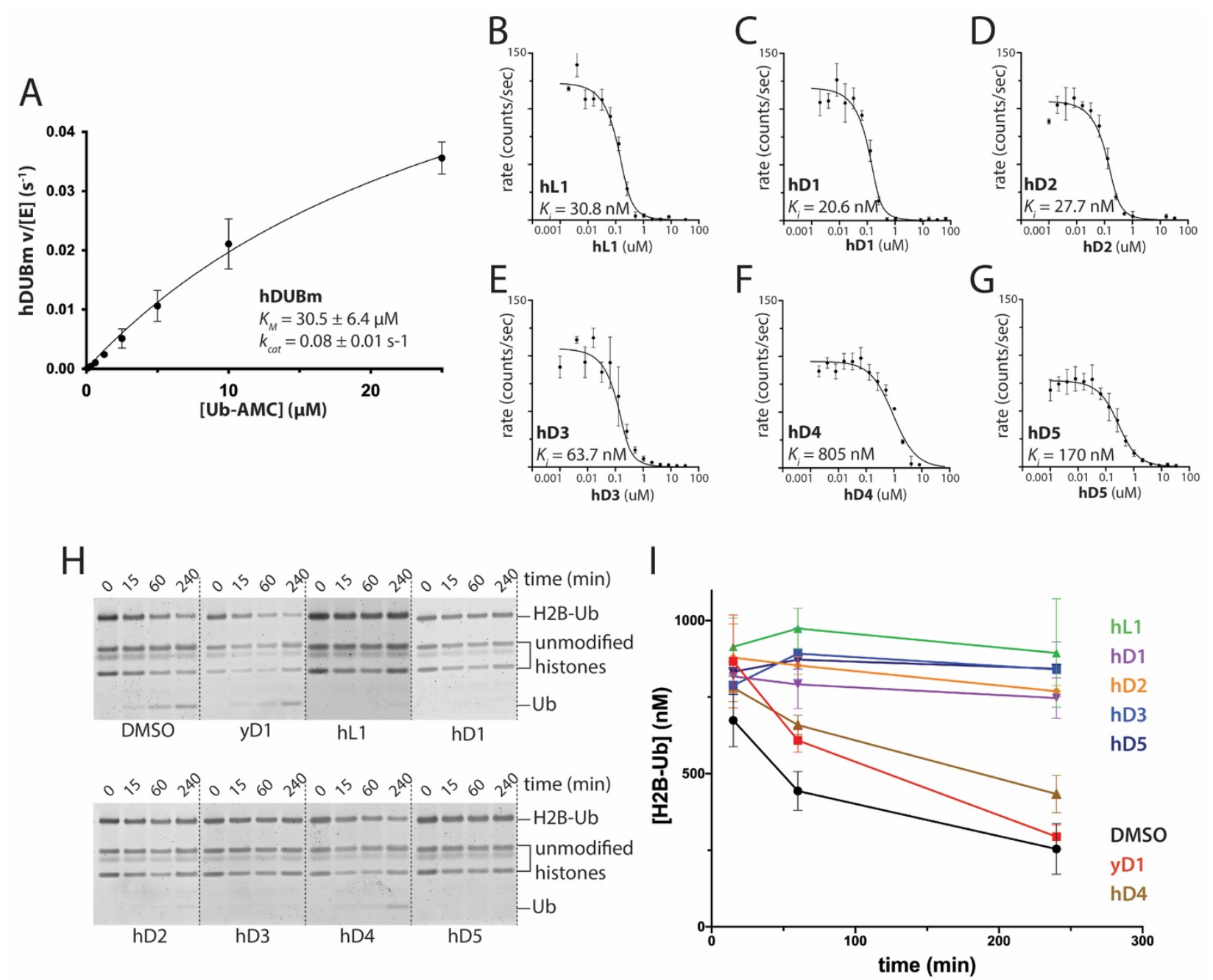

Figure 2 - Inhibition of human DUB module activity inhibition by cyclic peptides. A) Initial rates of Ub-AMC cleavage by hDUB module as a function of substrate concentration. Values of $k_{\text {cat }}$ and $K_{M}$ are indicated. B-G) Each indicated cyclic peptide was tested for its ability to inhibit Ub-AMC cleavage in the presence of increasing amounts of the peptide into a reaction with a fixed amount of DUB $(200 \mathrm{nM})$ and Ub-AMC $(1 \mu \mathrm{M})$. $\mathrm{K}_{\mathrm{i}}$ values were determined for each curve using the Morrison $\mathrm{K}_{\mathrm{i}}$ approximation. Inhibition of human DUB module activity on $\mathrm{H} 2 \mathrm{~B}$ ubiquitinated nucleosomes $\mathbf{H}$ ) Effect of each cyclic peptide (1 uM) and DMSO control on hDUB module cleavage rates on ubiquitinated nucleosomes. I) Quantitation of the disappearance of the H2B-Ub band, performed in triplicate. 


\section{Figure 3}
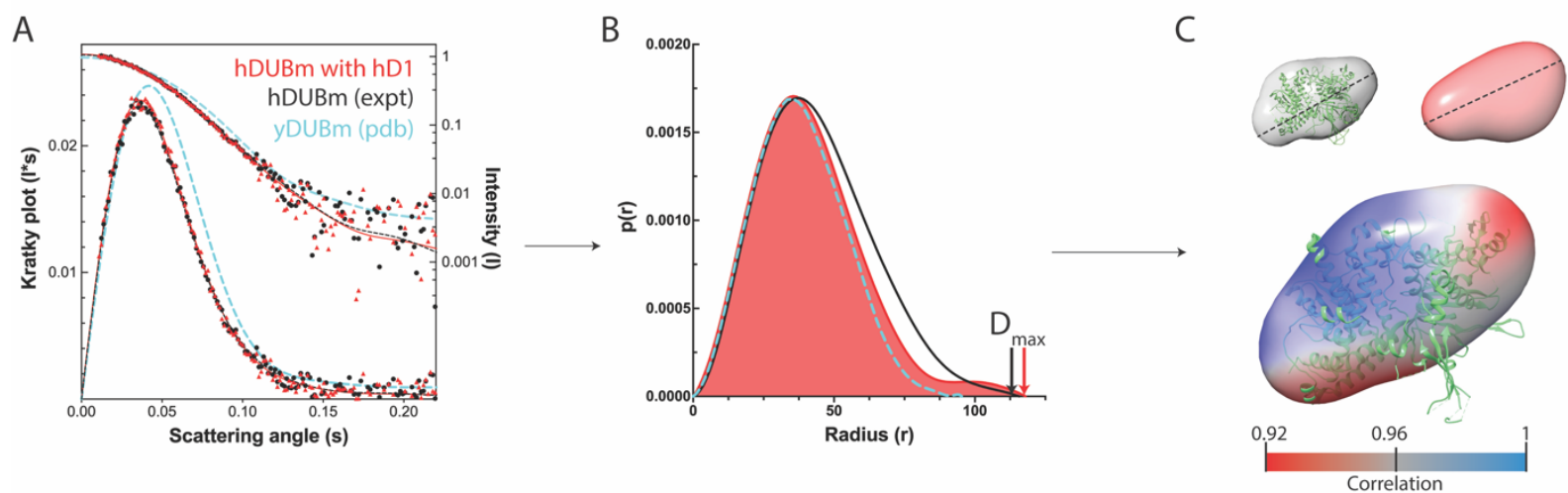

Figure 3 - Small angle $x$-ray scattering (SAXS) analysis of the DUB module in the presence and absence of cyclic peptide. A) Scattering intensities of $1 \mathrm{mg} / \mathrm{mL}(6 \mu \mathrm{M}) \mathrm{hDUBm}$ alone (black), $\mathrm{hDUBm}$ in the presence of $7 \mathrm{uM} \mathrm{hD1}$ (red), and theoretical scattering intensities calculated from the yDUBm crystal structure (PDB ID: $3 \mathrm{MHH}$, cyan). The right y-axis describes raw measured intensities (upper curve), while the left $y$-axis is a plot of I*s values (Kratky plot). B) Frequency distribution $(P(r))$ of possible vectors between surfaces on the scattering sample. Experimental curves from hDUBm (black) and hDUBm plus hD1 inhibitor (red); calculated curve for yDUBm (cyan). $D_{\max }$ is indicated by a colored arrow corresponding to each sample. C) Electron density maps derived from SAXS data of hDUBm alone (gray) and hDUBm in the presence of hD1 (red). Dashed line indicates $D_{\max }$. Correlations between the peptide-bound and apo complexes indicated by pseudocoloring (scale below). The yeast DUB module structure (green) was used to independently orient both density maps. 


\section{Figure 4}
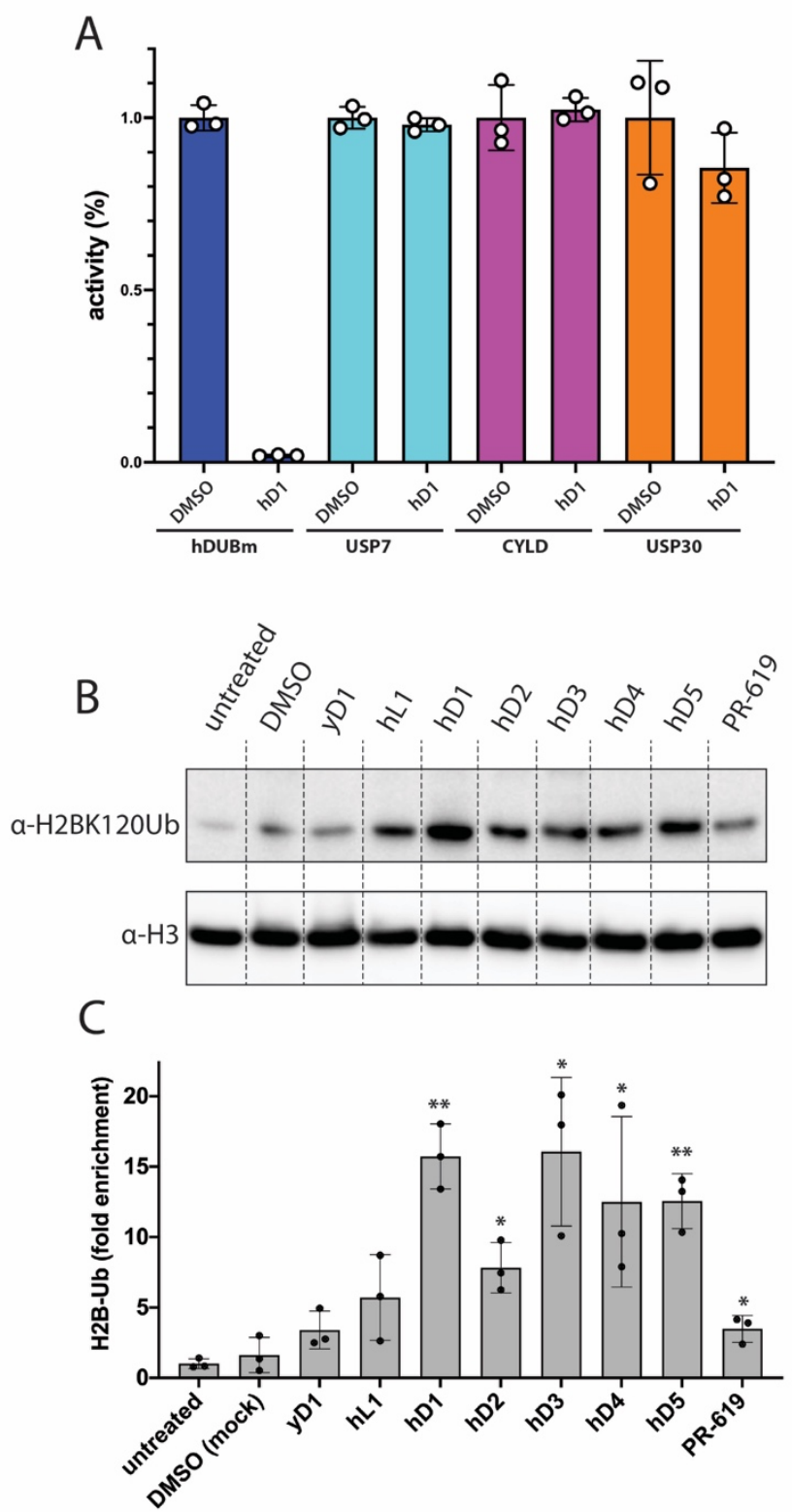

Figure 4 - A) hD1 is specific for the human DUB module. The bar graph showing normalized initial rates of Ub-AMC cleavage $(1 \mu \mathrm{M})$ by the indicated DUB in the presence or absence of inhibitor, hD1. Cleavage reactions contained either 200 nM hDUBm, 100 nM USP7CD, 100 nM CYLD, or $200 \mathrm{nM}$ USP30 in the presence of either DMSO (mock control) or hD1. B) Cyclic peptide inhibitors of hDUBm increase cellular H2B-Ub levels. HEK293T cells incubated with $5 \mu \mathrm{M}$ of each cyclic peptide. Histone proteins were extracted, and samples analyzed by western blot with anti-H2BK120ub antibody. Bottom: anti-histone H3 loading control. C) Quantitation of western results indicates significant enrichment of $\mathrm{H} 2 \mathrm{~B}-\mathrm{Ub}$ when normalized to $\mathrm{H} 3$ abundance. Bars labeled with two asterisks indicate $p<0.01$ (hD1 and hD5), and a single asterisk indicates $p$ $<0.05$ (hD2, hD3, hD4, and PR-619) when each measurement is compared with untreated cells. 


\section{SUPPLEMENTAL FIGURES}

A
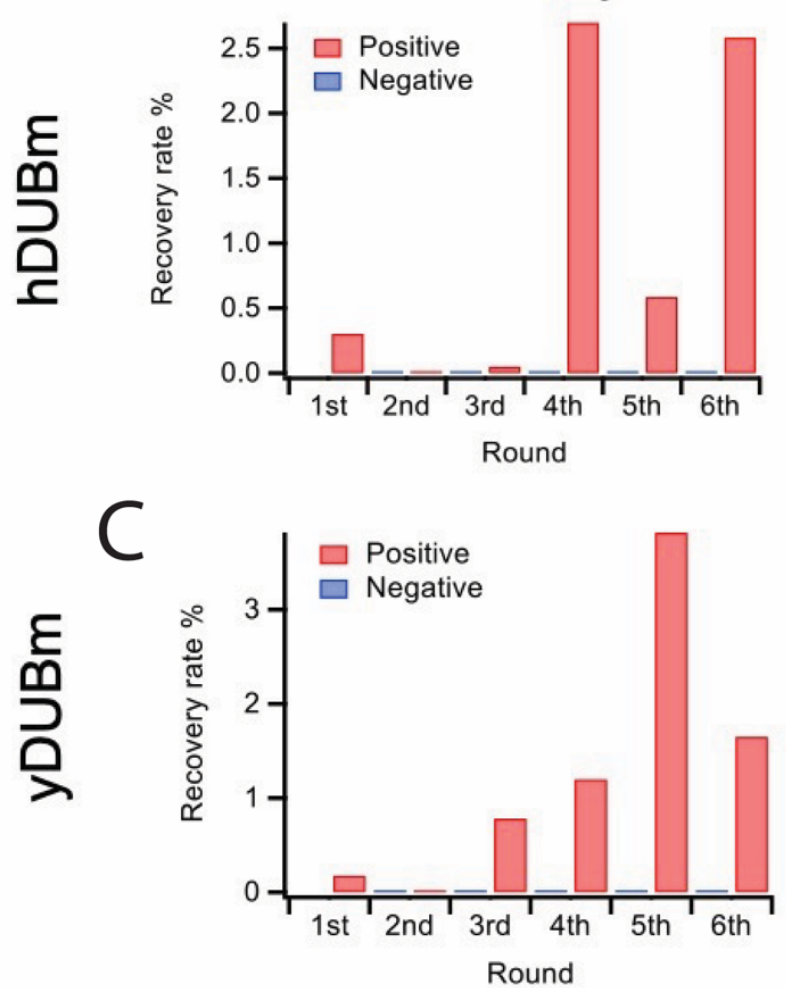

B

D-library
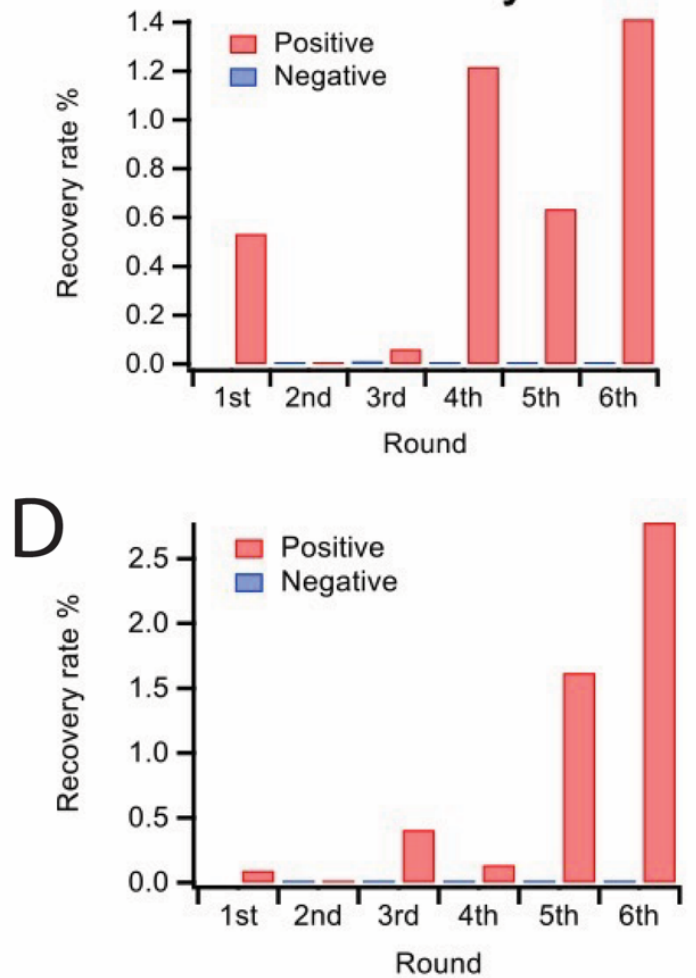

Supplemental Figure S1, related to Figure 1. Progress of selection for hDUBm from ${ }^{~} \mathrm{Y}$ library A) and ${ }^{D}$-library B), and for yDUBm from ${ }^{\text {' }}$-library C) and ${ }^{D} Y$-library D). Red and blue bars represent the recovery rate of the cDNAs eluted from peptide-mRNA complex binding to DUBm-immobilized magnetic beads and biotin bound magnetic beads, respectively. 
A

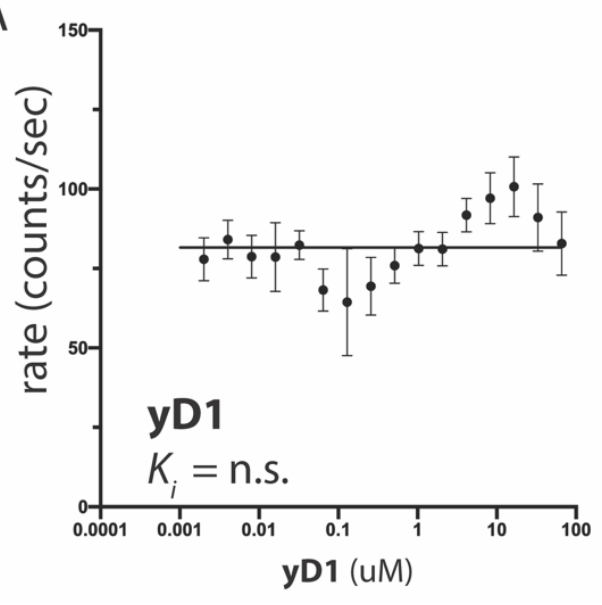

B

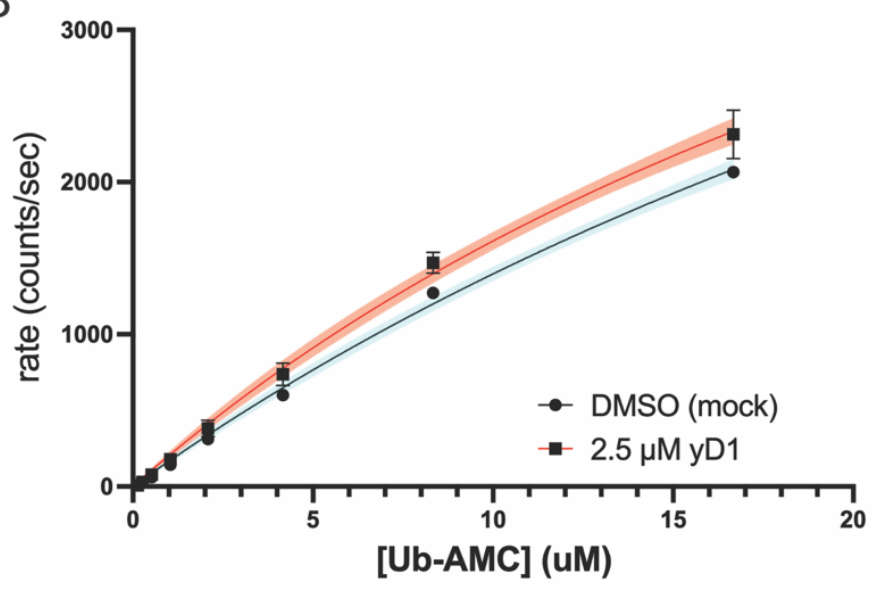

Supplemental Figure S2, Related to Figure 2. yD1 does not inhibit the human or yeast DUB modules. A) As in Figure 2, hDUBm enzymatic activity was asseyed in the presence of a range of yD1 concentrations. yD1 was selected in RaPID screening against the yeast DUB module, and thus a negative result was expected. yD1 was further used as a negative control in which a cyclic peptide is present but inactive. B) $50 \mathrm{nM}$ yeast DUB module was incubated with either DMSO (vehicle) or $2.5 \mu \mathrm{M}$ yD1 the peptide with the tightest binding to the yeast DUB module in RaPID screening. Each enzyme mixture was then mixed with a range of Ub-AMC concentrations, and cleavage was monitored by fluorescence. Rather than inhibition, yD1 produced a slight increase in cleavage rates. 

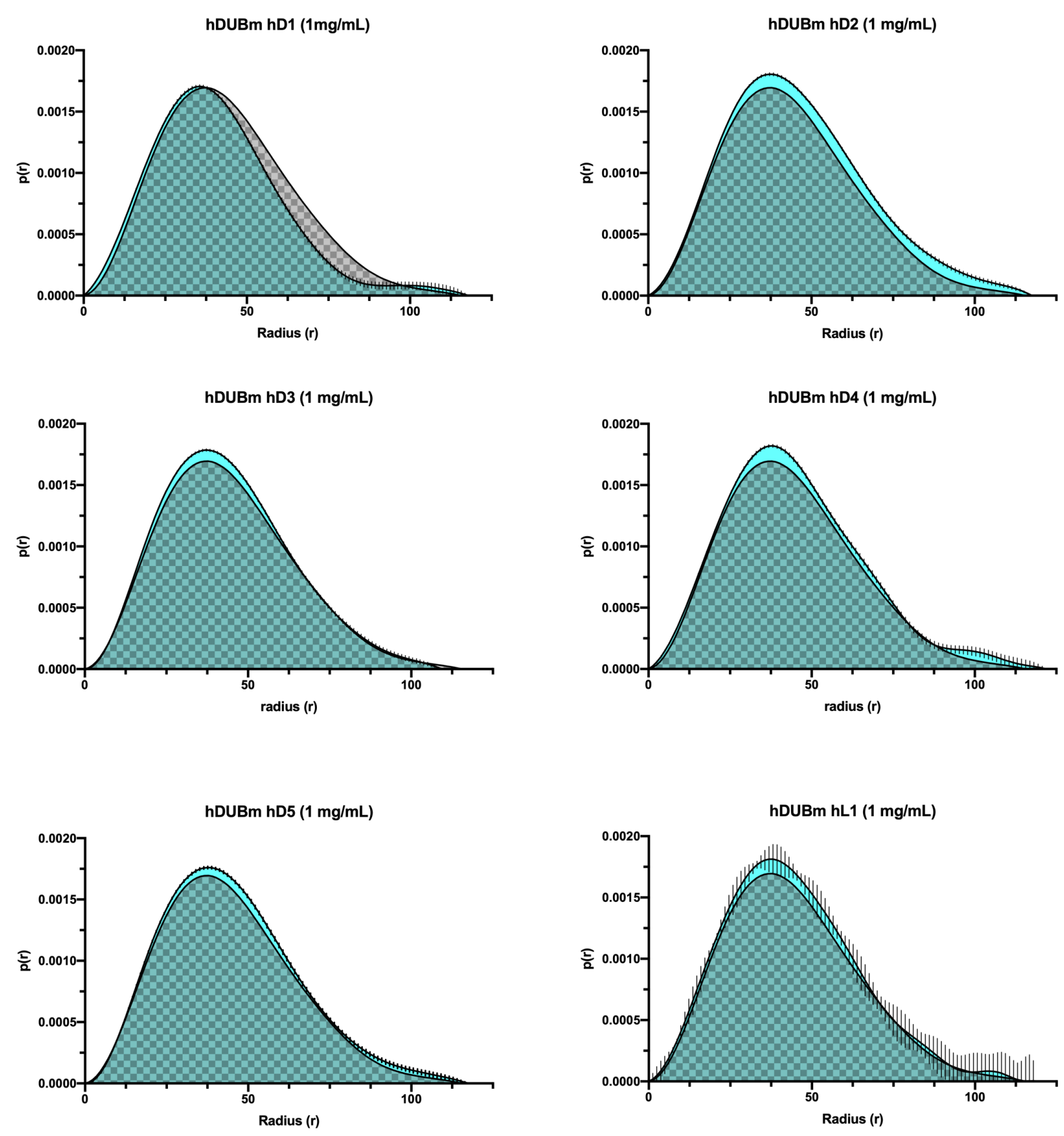

Supplemental Figure S3, Related to Figure 3. Pairwise vector distributions $[p(r)]$ calculated from SAXS data on the human DUB module collected in saturating amounts of each indicated peptide compared with data collected without peptide (checked fill). Cyan portions of the curve fill indicate differences in the $p(r)$ distribution due to peptide binding. In the case of hD1, peptide binding apparently contracts the complex at regions indicated by the grey checkered regions. 


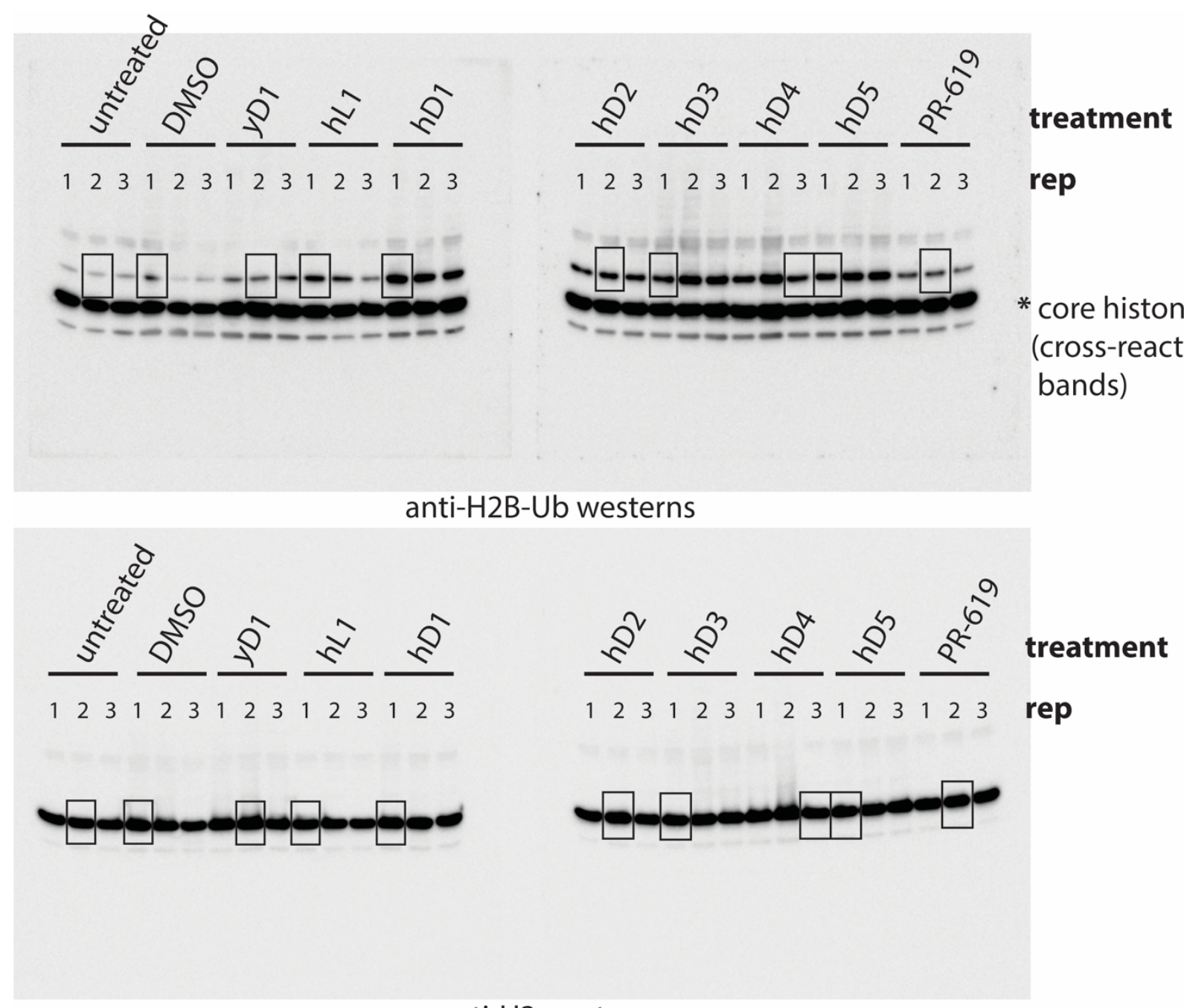

anti-H3 westerns

Supplemental Figure S4, related to Figure 4. Uncropped western blot images of anti$\mathrm{H} 2 \mathrm{~B}-\mathrm{Ub}$ and anti-H3 blots of identical gels normalized to H3 signals. HEK293T cells were incubated with $5 \mu \mathrm{M}$ of each indicated peptide. Each image contains two blots from two gels imaged side-by-side with three biological replicates of the indicated treatment. Lanes cropped as representative images for Fig 4B (main text) are indicated with boxed overlays. 